\title{
Sequence-dependent effects of ZDI839 ('Iressa') in combination with cytotoxic treatment in human head and neck cancer
}

\author{
N Magné', JL Fischel', A Dubreuil', P Formento', S Marcié', J-L Lagrange' and G Milano*,I \\ 'Department of Oncopharmacology, Oncopharmacology Unit, Centre Antoine Lacassagne, 33 Avenue de Valombrose, 06189 Nice Cedex 2, France
}

\begin{abstract}
Elevated levels of epidermal growth factor receptor in head and neck cancer have been extensively reported, and are correlated with poor prognosis. The combination of cisplatin and 5-fluorouracil is a standard treatment regimen for head and neck cancer, with radiation representing another therapeutic option. Six head and neck cancer cell lines were used to study the cytotoxic effects of combining ZDI839 ('Iressa'), a new selective epidermal growth factor receptor tyrosine kinase inhibitor, and radiation. Two of the cell lines were also used to study the combination of ZDI839 and cisplatin/5-fluorouracil. Cytotoxic effects were assessed by the MTT test. The results indicated that ZDI839 applied before radiation gave the best effects $(P=0.002)$; an effect that was strongest in those p53-mutated cell lines that express the highest epidermal growth factor receptor levels. The effects of ZDI 839 with cisplatin and/or 5 -fluorouracil were sequence dependent $(P<0.003)$, with the best results achieved when ZD 839 was applied first. For the triple combinations, ZD 1839 applied before cisplatin and 5fluorouracil resulted in a slight synergistic effect $(P=0.03)$, although the effect was greater when ZDI839 was applied both before and during cytotoxic drug exposure. In conclusion, ZD I 839 applied before radiation and before and/or during cisplatin/ 5 -fluorouracil may improve the efficacy of treatment for head and neck cancer.

British Journal of Cancer (2002) 86, 819-827. DOI: 10.1038/sj/bjc/6600I03 www.bjcancer.com
\end{abstract}

(c) 2002 Cancer Research UK

Keywords: ZD 1839; fluorouracil; cisplatin; radiation; head and neck cancer cell lines; combination therapy

Epidermal growth factor receptor (EGFR) has been particularly well studied in head and neck cancer (HNC) because of its association with the cellular mechanisms involved in tumour progression. High levels of EGFR expression have been correlated with poor prognosis (Santini et al, 1991; Dassonville et al, 1993). EGFR signalling has been found to control not only cell growth, but also angiogenesis and DNA repair (Wheeler et al, 1999; Schlessinger, 2000), and has recently been assessed as an innovative target in cancer therapy and particularly in HNC. To date, clinical studies in this area have involved the administration of cetuximab (C225, a chimeric monoclonal antibody), either alone or in combination with chemotherapy or radiotherapy, to patients with advanced head and neck squamous cell carcinoma (Ezekiel et al, 1999; Huang et al, 1999; Mendelsohn et al, 1999; Baselga et al, 2000; Huang and Harari, 2000; Milas et al, 2000). More recently, a wide range of small-molecule tyrosine kinase inhibitors have been developed, and one of the most advanced in this class of compounds is ZD1839 ('Iressa'), which is a quinazoline derivative. This agent interacts specifically with the highly conserved ATP binding site of the tyrosine kinase domain of EGFR, resulting in inhibition of ligand-induced EGFR activation, and blockade of signal transduction pathways (Ciardiello et al, 2000; Sirotnak et al, 2000).

The cisplatin/5-fluorouracil (5-FU) regimen is considered to be a standard chemotherapy regimen in the treatment of advanced HNC as part of an organ-conserving strategy (Taylor et al, 1997; Brizel et al, 1998; Calais et al, 1999). Another standard treatment

*Correspondence: G Milano; E-mail: gérard.milano@cal.nice.fnclcc.fr Received 9 August 200I; revised 23 November 200I; accepted 23 November 2001 is the combination of external beam radiation therapy with surgical extirpation (Bensadoun et al, 1998; Fu et al, 2000; Vokes et al, 2000). Despite the effectiveness of these treatments, the survival rates vary according to the tumour site and stage, and globally, prognosis remains poor (Vokes et al, 1993). Thus, one interesting and promising research direction for altering the natural history of HNC could be a molecular-targeted therapy against EGFR in association with one of the standard therapeutic strategies. Experimental data have indicated that application of EGFR-targeting agents can not only slow down cell proliferation, but also improve apoptotic capacities and decrease DNA repair. These observations suggest that EGFR targeting can lead to chemo- and radiosensitisation and recent experimental results tend to confirm this view (Huang et al, 1999).

The aim of this study was two-fold: firstly, to explore the sequence-dependent cytotoxic effects of combining ZD1839 with radiation using a panel of six human head and neck squamous cell carcinoma cell lines; and secondly, to investigate the sequencedependent cytotoxic effects of combining ZD1839 with cisplatin and/or 5-FU on two of the cell lines from the panel. This preclinical work was undertaken to serve as a rationale to support ongoing clinical investigations of ZD1839 in HNC patients.

\section{MATERIALS AND METHODS}

\section{Chemicals}

ZD1839 was kindly provided by AstraZeneca. A $50 \mathrm{~mm}$ working solution in dimethysulphoxide (DMSO) was prepared before use. Human recombinant ${ }^{125}$ I-EGF (ref IM 196, specific activity $4514 \times 10^{10} \mathrm{~Bq} \mathrm{mmol}^{-1}, 92.5 \times 10^{4} \mathrm{~Bq}$ per $\left.250 \mu \mathrm{l}\right)$ and unlabelled human recombinant EGF (ref ARN 5100) were obtained from 
Amersham. Dulbecco's modification of Eagle's medium (DMEM) RPMI 1640 and glutamine were purchased from Whittaker (Verviers, Belgium). Foetal bovine serum (FBS) was obtained from Dutscher (Brumath, France). Penicillin and streptomycin were from Meyrieux (Lyons, France). Transferrin and insulin were purchased from Flow (Irvine, Scotland). Bovine serum albumin (BSA), 3-(4-5-dimethylthiazol-2-yl)-2,5-diphenyl tetrazolium bromide (MTT) and DMSO were purchased from Sigma (St Quentin Fallavier, France).

\section{Cell lines}

Six HNC cell lines of human origin were used (CAL27, CAL33, CAL60, CAL166, Hep-2, Detroit562) (Table 1). Cells were routinely cultured in DMEM supplemented with $10 \%$ FBS, 2 mM glutamine,

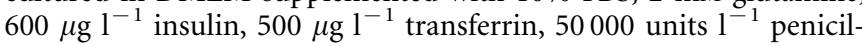
lin and $80 \mu \mathrm{M}$ streptomycin in a fully humidified incubator (Sanyo, Japan) at $37^{\circ} \mathrm{C}$ in an atmosphere containing $8 \% \mathrm{CO}_{2}$.

\section{EGFR assay}

EGFR expression was assayed by competitive analysis and Scatchard plots as previously described in human cancer cell lines (Olivier et al, 1990). Cells were grown in 24 -well plates $\left(10^{5}\right.$ cells per well) in $10 \%$ FBS-DMEM at $37^{\circ} \mathrm{C}$. At $80-90 \%$ confluence, cells were rinsed three times with $500 \mu \mathrm{l}$ RPMI 1640 containing $0.1 \% \mathrm{BSA}$ at $2-4^{\circ} \mathrm{C}$ (plates placed on a tray with ice). Plates were then incubated for $30 \mathrm{~min}$ with the same medium (500 $\mu$ l per well) at $4^{\circ} \mathrm{C}$. Cells were first screened for their capacity to bind EGF specifically. Total binding was measured after incubation with $0.2 \mathrm{nM}{ }^{125} \mathrm{I}$-EGF ( $3 \mathrm{~h}, 4^{\circ} \mathrm{C}, 0.1 \% \mathrm{BSA}-\mathrm{RPMI}$ ); non-specific binding was measured in the presence of an excess of unlabelled EGF $(20 \mathrm{nM})$. With no exception, the six tested cell lines exhibited EGF binding and their precise EGFR content was then measured. Cells were incubated in the RPMI medium for $3 \mathrm{~h}$, at $4^{\circ} \mathrm{C}$ in the presence of various concentrations of ${ }^{125}$ I-EGF $(0.01,0.02,0.04$, $0.08,0.12,0.18,0.20 \mathrm{nM}$ ); for higher EGF concentrations, cells were incubated with $0.2 \mathrm{nM}{ }^{125} \mathrm{I}$-EGF with increasing concentrations of unlabelled EGF (0.05, 0.1, 0.2, 0.4, 0.8, 1.6, 3.2, 6.4, 20, $200 \mathrm{nM})$. Plates were placed on ice to stop the reaction, and the supernatant was removed from each well. Cells were washed twice with phosphate-buffered saline (PBS) containing $0.1 \%$ BSA $\left(4^{\circ} \mathrm{C}, 500 \mu \mathrm{l}\right.$ per well). After removal of the supernatant, cells were solubilised in $1 \mathrm{M} \mathrm{NaOH}$ at $37^{\circ} \mathrm{C}(500 \mu \mathrm{l}$ per well for $30 \mathrm{~min})$. The radioactivity of each well was determined by gamma counting. Results were expressed in fmol per mg cell protein. Scatchard analysis was used to calculate the number of receptor sites per cell $(\mathrm{N})$ and the dissociation constant $\left(\mathrm{K}_{\mathrm{d}}\right)$. Each point of every Scatchard plot was performed in quadruplicate. Cells were counted in four wells run in parallel, resuspended in $200 \mu \mathrm{l}$ PBS at room temperature and counted with a haemocytometer. Experiments were performed in duplicate only, because of the intrinsic reproducibility of the assay (coefficient of variance $=7.3 \%, n=4$ ).

\section{Determination of p53 status}

DNA was extracted from all head and neck cell lines of the panel. Exons 4 to 8 were screened for mutations by use of denaturing gradient gel electrophoresis in accordance with the method described by Hamelin et al (1993) for exons 5, 7, and 8, and the method of Gulberg et al (1997) for exons 4 and 6. Exon 9 was screened for mutations by the method described by Cabelguenne et al (2000). Polymerase chain reaction (PCR) amplification products were loaded onto a $6.5 \%$ polyacrylamide gel that contained an appropriate gradient of urea and formamide. After electrophoresis, gels were stained with ethidium bromide. Tumours that showed an electrophoresis variant pattern were amplified and sequenced for each variant exon. PCR products were purified with QIAquick PCR Purification Kit (QIAGEN SA, Courtabeuf, France) and sequenced on both strands on an $\mathrm{ABI} 310$ genetic analyser (PE Applied Biosystems, Courtabeuf, France). A Big Dye Terminator sequencing kit (PE Applied Biosystems) was used in accordance to the manufacturer's instructions; this step was followed by ethanol precipitation to remove non-incorporated dyes. Sequences were analysed by Sequence Analysis 3.0 (PE Applied Biosystems).

\section{Evaluation of radiotoxicity}

Cells were irradiated with gamma rays during exponential cell growth as monolayers in 96-well microtitration plates using a ${ }^{60} \mathrm{Co}$ unit at a dose rate of $1 \mathrm{~Gy} \mathrm{~min}^{-1}$. Dose-effect curves were established for all six head and neck cell lines using a total of 10 doses $(0.5,1,2,3,4,6,8,10,12,15$ Gy). Sequence-dependent cytotoxic effects of binary combinations of ZD1839 (0.2$200 \mu \mathrm{M})$ with ionising radiation were then evaluated using eight doses of ionising radiation, ranging from 0.5 to $10 \mathrm{~Gy}$ for CAL27 and CAL33, and from 2 to $15 \mathrm{~Gy}$ for CAL60, CAL166, Hep-2 and Detroit562 (the radiation doses were selected from the above experiments to encompass more precisely the zone of sensitivity). Cells were maintained in DMEM supplemented with 10\% FBS during all radiation exposures, which were performed at room temperature.

\section{Determination of the cytotoxic effects of radiation alone}

Cells were seeded in 96-well microtitration plates (100 $\mu \mathrm{l}$ per well) to obtain exponential growth for the whole duration of the experiment: initial cell densities were 2500 (CAL27 and Hep-2), 3000 (CAL33 and Detroit562), 4500 (CAL166) and 5000 (CAL60) cells per well.

The cells were exposed to ionising radiation $48 \mathrm{~h}$ later (dose previously described) and the MTT assay was performed $48 \mathrm{~h}$ after that. Control cells received no radiation treatment.

Determination of cytotoxicity using ZD1839 in combination with radiation Cells were seeded in 96-well microtitration plates (100 $\mu \mathrm{l}$ per well) to obtain exponential growth for the whole dura-

Table I Head and neck cancer cell line characteristics ${ }^{a}$

\begin{tabular}{|c|c|c|c|c|c|c|c|c|}
\hline Cell line & Origin & $\begin{array}{c}\text { EGFR levels } \\
\text { (fmol } \mathrm{mg}^{-1} \text { protein) }\end{array}$ & p53 status & $\begin{array}{l}\text { Doubling } \\
\text { time (h) }\end{array}$ & $\begin{array}{l}\mathrm{IC}_{50} \\
\text { radiation }(\mathrm{Gy})\end{array}$ & $\begin{array}{c}\text { IC }_{50} \\
\text { cisplatin }(\mu \mathrm{M})\end{array}$ & $\begin{array}{c}\mathbf{I C}_{\mathbf{5 0}} \\
\text { 5-FU }(\mu \mathrm{M})\end{array}$ & $\begin{array}{c}\text { IC }_{\mathbf{5 0}} \\
\text { ZDI839 }(\mu \mathrm{M})\end{array}$ \\
\hline CAL27 & CAL & $8258(3 \mid 1)$ & mutant (exon 6) & | $8.2(1.5)$ & $6.2(1.1)$ & $2.4(0.1)$ & $4.1(0.8)$ & $17.5(2.4)$ \\
\hline CAL33 & CAL & $33794(624)$ & mutant (exon 5) & $17.5(0.1)$ & $2.6(0.4)$ & $5.7(1.2)$ & $2.7(1.9)$ & $6.07(0.8)$ \\
\hline CAL60 & CAL & 2703 (101) & mutant (exon 7) & | $1.8(0.2)$ & $5.1(0.1)$ & $2.2(0.1)$ & I.I (0.2) & | $1.4(0.9)$ \\
\hline CALI 66 & $\mathrm{CAL}$ & $3253(126)$ & wild type & |3.1 (1.0) & $6.2(0.8)$ & $9.7(0.6)$ & $5.4(0.6)$ & $22.8(4.8)$ \\
\hline Hep-2 & ATCC & $388(27)$ & wild type & $10.9(1.0)$ & $9.8(0.3)$ & $7.1(1.7)$ & $5.6(1.0)$ & $31.1(2.4)$ \\
\hline Detroit562 & ATCC & $668(45)$ & mutant (exon 5) & | $4.8(0.4)$ & $7.7(0.1)$ & $12.6(1.1)$ & $31.7(1.1)$ & $20.6(1.5)$ \\
\hline
\end{tabular}

a Mean values (standard deviation), at least two separate experiments done at distance for EGFR content, and three different experiments for other determinations; CAL, Center Antoine Lacassagne; ATCC, American Type Culture Collection, Rockville. 
tion of the experiment (initial cell density is given above). In each plate, one ZD1839 concentration and one radiation dose were tested. Only half of each plate was irradiated in order to measure on the same plate the effects of ZD1839 alone (20 wells), radiation alone (five wells), ZD1839 combined with radiation (20 wells) and a control (no radiation, no ZD1839; five wells).

Forty-eight hours after seeding the cells, three different sequences of radiation and 48-h incubations of ZD1839 were compared: (a) ZD1839 (48 h) followed by radiation, then medium for $48 \mathrm{~h}$; (b) concomitant ZD1839 (48 h) and ionising radiation (radiation delivered in the middle of ZD1839 exposure), followed by medium for $48 \mathrm{~h}$; (c) ionising radiation prior to ZD1839 $(48 \mathrm{~h})$, then medium for $48 \mathrm{~h}$.

Growth inhibition was assessed $168 \mathrm{~h}$ after cell seeding by using the MTT test as described below (Carmichael et al, 1987). Cells were washed with PBS and incubated with MTT; after $2 \mathrm{~h}$ of exposure, MTT was released and fixation was revealed by the addition of DMSO $(100 \mu \mathrm{l})$. Absorbance at $450 \mathrm{~nm}$ was measured using a microplate reader (Labsystems, Helsinki, Finland). Results were expressed as the relative percentage of absorbance compared with controls without drug. Cell sensitivity to the tested drugs was expressed by $\mathrm{IC}_{50}$ (concentration leading to $50 \%$ cell survival). Triplicate determinations were made in separate experiments.

\section{Evaluation of cisplatin and/or 5-FU cytotoxicity}

Cells were seeded in 96-well microtitration plates (100 $\mu$ l per well) to obtain exponential growth for the duration of the experiments (initial cell density was 2500 and 3000 cells per well for Hep-2 and CAL33, respectively). Forty-eight hours after seeding, cells were exposed to ZD1839 and cisplatin and/or 5-FU in a variety of sequences. In all cases, cells were exposed to ZD1839 for $48 \mathrm{~h}$, and the cisplatin/5-FU sequence was constant (cisplatin applied for $2 \mathrm{~h}$ prior to exposure to 5-FU for $48 \mathrm{~h}$ ). The sequence of ZD1839 varied: (a) ZD1839 (48 h) followed by cisplatin and/or 5-FU; (b) concomitant ZD1839 and cisplatin and/or 5-FU (the exposure to ZD1839 was $50 \mathrm{~h}$ ); (c) ZD1839 prior to and during cisplatin/5-FU exposure (ZD1839 was given for $48 \mathrm{~h}$ before cisplatin/5-FU and then for $50 \mathrm{~h}$ concomitant with cisplatin/5-FU, making $98 \mathrm{~h}$ in total) followed by medium for $48 \mathrm{~h}$; (d) cisplatin/5-FU prior to ZD1839 followed by medium for $48 \mathrm{~h}$. Eleven concentrations were tested for each drug: ZD1839 $0.2-200 \mu \mathrm{M}$; cisplatin $0.1-200 \mu \mathrm{M}$; 5-FU $0.22-$ $220 \mu \mathrm{M}$. The cisplatin/5-FU combination was tested at a constant concentration ratio of the drugs for a given cell line, the ratio being dictated by the drug sensitivity and close to the ratio of the $\mathrm{IC}_{50}$ for each drug.

Thereafter, growth inhibition was assessed $48 \mathrm{~h}$ after the end of the experiment (in medium alone) by the MTT test described above. Experimental conditions were tested in sextuplicate (six wells of the 96-well plate per experimental condition) and separate experiments were performed in triplicate. The dose-effect curves were analysed using Prism software (GraphPad Software, San Diego, CA, USA).

\section{Combination index (CI) calculations and determination of the potentiation factor}

The cytotoxic effects obtained with the different ZD1839/cisplatin/ 5 -FU combinations were analysed according to the Chou and Talalay (1984) method on Calcusyn software (Biosoft, Cambridge, UK). Interaction between the double combinations (ZD1839 plus either cisplatin or 5-FU), or the triple combinations (ZD1839 plus cisplatin and 5-FU) was assessed by means of an automatically computed combination index (CI). CI was determined at 50 and $75 \%$ cell death, and was defined as follows:
$\mathrm{CI}_{\mathrm{A}+\mathrm{B}}=\left[\left(\mathrm{D}_{\mathrm{A} / \mathrm{A}+\mathrm{B}}\right) / \mathrm{D}_{\mathrm{A}}\right]+\left[\left(\mathrm{D}_{\mathrm{B} / \mathrm{A}+\mathrm{B}}\right) / \mathrm{D}_{\mathrm{B}}\right]+\left[\alpha\left(\mathrm{D}_{\mathrm{A} / \mathrm{A}+\mathrm{AB}} \times \mathrm{D}_{\mathrm{B} / \mathrm{A}+\mathrm{B}}\right) / \mathrm{D}_{\mathrm{A}} \mathrm{D}_{\mathrm{B}}\right]$ where $\mathrm{CI}_{\mathrm{A}+\mathrm{B}}=\mathrm{CI}$ for a fixed effect $(\mathrm{F})$ for the combination of cytotoxic $\mathrm{A}$ and cytotoxic $\mathrm{B}$.

$\mathrm{D}_{\mathrm{A} / \mathrm{A}+\mathrm{B}}=$ concentration of cytotoxic $\mathrm{A}$ in the combination $\mathrm{A}+\mathrm{B}$ giving an effect $\mathrm{F}$.

$D_{B / A+B}=$ concentration of cytotoxic $B$ in the combination $A+B$ giving an effect $F$.

$\mathrm{D}_{\mathrm{A}}=$ concentration of cytotoxic A alone giving an effect $\mathrm{F}$.

$\mathrm{D}_{\mathrm{B}}=$ concentration of cytotoxic $\mathrm{B}$ alone giving an effect $\mathrm{F}$.

$\alpha=$ parameter with value 0 when $\mathrm{A}$ and $\mathrm{B}$ are mutually exclusive and

1 when $\mathrm{A}$ and $\mathrm{B}$ are mutually non-exclusive.

The combination index indicated: synergism $<0.8$; additivity $>0.8$ and $<1.2$; antagonism $>1.2$; slight synergistic and additive cytotoxic activity for values of 0.8 and 1.2 , respectively.

The cytotoxic effects obtained with the different ionising radiation/ZD1839 combinations were also analysed according to the Chou and Talalay (1984) method as described above. CIs were determined at 50 and $75 \%$ cell death. The application of the Chou and Talalay model recommends the use of cytotoxic agents at a fixed dose ratio (for example, the ratio of their $\mathrm{IC}_{50} \mathrm{~s}$ ). However, in the case of ZD1839 and radiation, this strategy would not have been feasible because the dose-effect curves of each cytotoxic agent acting alone are too different (e.g. $\mathrm{IC}_{90} / \mathrm{IC}_{10}=50$ for $\mathrm{ZD} 1839$ and 2.8 for radiation (CAL33 cell line)). Consequently, ZD1839 and radiation were combined at equitoxic effects (i.e. doses were applied in the combination that would have produced the same cytotoxic effect if given alone); it follows that the ratio between the concentration of ZD1839 and the radiation dose varied from $4 \times 10^{-7}$ up to $2 \times 10^{-5}$ when progressing from low to high cytotoxic effect. When using non-constant ratios between the doses, the Chou and Talalay Calcusyn programme does not allow direct calculation of the CIs at a fixed final cell death (50 and $75 \%$ in the present case). Thus, in order to compare $\mathrm{CI}$ at fixed values, i.e. $\mathrm{CI}_{50}$ or $\mathrm{CI}_{75}$, we graphically interpolated between values obtained from the experimental points (11 points generated by the programme between 10 and $90 \%$ of final death).

The potentiation factor of ionising radiation by ZD1839 was defined as the ratio of the $\mathrm{IC}_{50}$ of ionising radiation alone to the $\mathrm{IC}_{50}$ of the combination (ZD1839 plus ionising radiation); higher potentiation factors indicate greater cytotoxicity. Potentiation factor I was obtained using sequence I (ZD1839 (48 h) followed by radiation, then medium for $48 \mathrm{~h}$ ). Potentiation factor II used sequence II (concomitant ZD1839 (48 h) and ionising radiation, radiation delivered in the middle of the ZD1839 exposure), and potentiation factor III used sequence III (ionising radiation prior to ZD1839 (48 h), then medium for $48 \mathrm{~h}$ ).

\section{Statistical analysis}

For the panel of cell lines, the relationship between EGFR expression and response to ionizing radiation was analysed by plotting $\mathrm{IC}_{50}$ values for radiation against the respective EGFR content. The Friedman non-parametric rank test was used to analyse the impact of the sequence ZD1839/cisplatin/5-FU (CI values) or ZD1839/radiation and to compare the different sequences combining ZD1839 and radiation on the basis of the potentiation factors. The correlation coefficients $(r)$ and the $P$-values were computed using SPSS software (Chicago, IL, USA). A $P$-value of less than 0.05 was considered to be statistically significant

\section{RESULTS}

The study panel of human squamous cell carcinoma cells showed substantial variability in EGFR expression, ranging from 388 
(Hep-2) to 33794 (CAL33) fmol per mg cell protein. Four of the six cell lines were found to be mutated for p53 gene; CAL166 and Hep-2 were p53 wild type (Table 1).

Hep-2 cells were the most radioresistant $\left(\mathrm{IC}_{50} 9.8 \pm 0.3 \mathrm{~Gy}\right)$, and CAL33 cells the most radiosensitive ( $\mathrm{IC}_{50} 2.6 \pm 0.4 \mathrm{~Gy}$ ). Figure 1 shows dose-survival curves following irradiation for Hep-2 and CAL33 cells. Over the panel of cell lines, growth inhibition was more pronounced in EGFR-overexpressing cell lines than it was in cell lines expressing low levels of EGFR (Table 1). A statistically significant linear inverse correlation was found between EGFR cellular content and $\mathrm{IC}_{50}$ for radiation $\left(P=0.0091, r^{2}=0.848\right)$ (Figure 2). No statistically significant correlation was found between EGFR levels and cell doubling time for the six head and neck cell lines $\left(P=0.093, r^{2}=0.548\right)$.

Typical dose-effect curves for the different ZD1839/radiation exposure combinations are shown in Figure 3 for CAL33. In all cell lines, pretreatment with ZD1839 followed by ionising radiation (sequence I) produced a leftward shift of the concentrationresponse curves, indicating a greater cytotoxic effect. The CI values computed at 50 and $75 \%$ cell lethality are given in Table 2 . It appears that ZD1839 applied $48 \mathrm{~h}$ before radiation (sequence I) led to lower $\mathrm{CI}$ values in all head and neck cell lines $(P=0.002)$. More precisely the best synergistic effects were observed in the p53-mutant cell lines that express the highest EGFR levels (CAL27, CAL33, CAL60). Typical examples of CI/fractional effect curves are illustrated in Figure 4 for CAL33.

Table 3 gives the potentiation factors for ZD1839 and ionizing radiation. Statistical analyses indicated that the relative contribu-

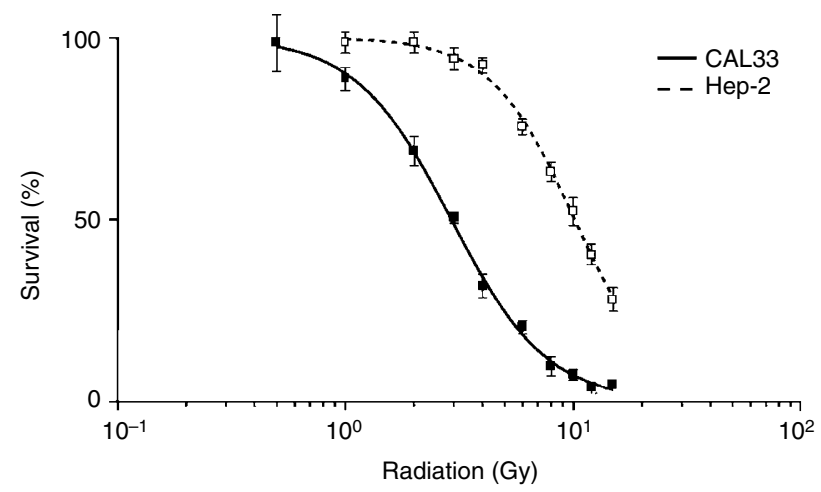

Figure I Dose-survival curves following ionising radiation for Hep-2 and CAL33 cells

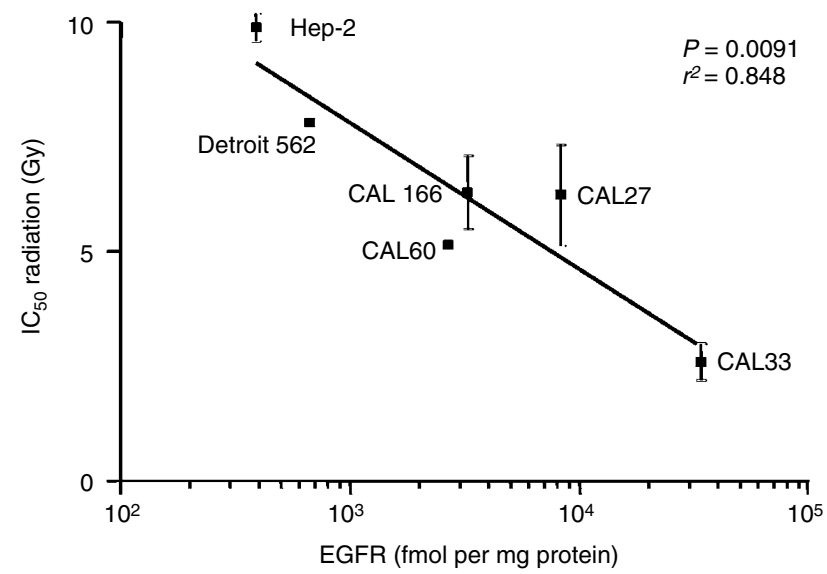

Figure 2 Correlation between cell sensitivity to ionising radiation and EGFR content. tions of the two treatments are significantly different depending upon the sequence $(P=0.001)$. The greatest contribution to the overall cytotoxicity of the combination came from ZD1839 applied $48 \mathrm{~h}$ before irradiation (sequence I; highest relative contribution) and the smallest from ZD1839 following irradiation (sequence III).

The order of association between ZD1839 and combined cytotoxic drugs had a significant impact on their interaction. For both cell lines, application of the Wilcoxon test shows that the association between ZD1839 and cisplatin alone gives supraadditive effects more frequently when ZD1839 is applied first; the same conclusions are true for ZD1839 combined with 5-FU, with mainly synergistic effects when ZD1839 is given before 5-FU ( $P$ $<0.003$ ) (Table 4). When ZD1839 was applied during or after each of these drugs, effects were usually additive or antagonistic. With the triple combination (ZD1839, cisplatin, 5-FU), the effects were synergistic when ZD1839 was applied first, in both Hep-2 and CAL33 cells $(P=0.003)$ (Table 4$)$. In contrast, when ZD1839 was applied during or after cisplatin/5-FU there were antagonistic or additive effects. Interestingly, the optimal result (lowest CI value) was obtained with sequence III, in which ZD1839 is applied before and during cisplatin/5-FU (Table 4). Typical dose-effect curves comparing sequences I and III are given in Figure 5 for Hep-2 and CAL33.

\section{DISCUSSION}

Squamous cell carcinomas in the aerodigestive tract remain a significant public health problem (Vokes et al, 1993). Even with multimodal therapy, the long-term remission rate for these cancers is only around $50-60 \%$. External beam radiotherapy represents one of the main therapeutic tools in HNC, producing major antitumour responses when used in conjunction with both cisplatin and 5-FU in either induction or adjuvant treatment settings (Vokes et al, 2000). A recent meta-analysis has shown that a substantial survival benefit can be obtained by chemo-/radiotherapy combination in advanced HNC (Pignon et al, 2000). The challenge in this pathology is to incorporate new agents into established regimens in order to obtain a significant impact on overall outcome. Over the past decade, comprehensive data have been accumulated that strongly support a role for EGFR and its ligands in tumour development and growth. This is particularly true for squamous cell carcinoma of the head and neck, where EGFR is considered to be one of the major prognostic factors (Santini et al, 1991; Dassonville et al, 1993; Salomon et al, 1995; Grandis et al, 1996, 1998; Maurizi et al, 1996). As a result, EGFR has become an attractive target for novel anticancer therapies, particularly in HNC.

Previous studies have shown that stimulation of the EGFR signalling pathway leads to radioresistance both in vitro and in vivo (Wollman et al, 1994; Miyaguchi et al, 1998; Akimoto et al, 1999; Dent et al, 1999). Interestingly, in the present study, we observed a strong positive association between EGFR level and radiosensitivity, which is in agreement with previous results of Bonner et al (1994, 1998, 2000). Among a panel of human tumour cell lines, these authors found that the cell line expressing the lowest EGFR levels demonstrated the greatest radioresistance, and that the greatest growth inhibition was observed for the cell line with the highest EGFR content. In addition, there are some in vitro reports suggesting an EGF-related radiosensitisation. For instance, Kwok and Sutherland $(1989,1991)$ have shown that EGF-related radiosensitization may be EGFR-density dependent. A link between the presence of transforming growth factor alpha (TGF $\alpha$ ) and radiosensitivity was also suggested by the clinical data reported by Sauter et al (1994) and Wen et al (1996). More precisely, Sauter et al (1994) found that low plasma TGF $\alpha$ levels were associated with radioresistance in patients with squamous carcinoma of the tongue. Wen et al (1996) reported that the recurrence rates of early laryngeal cancer treated with radiotherapy correlated with TGF $\alpha$ but not with EGFR. Thus, it appears that not only EGFR but also 

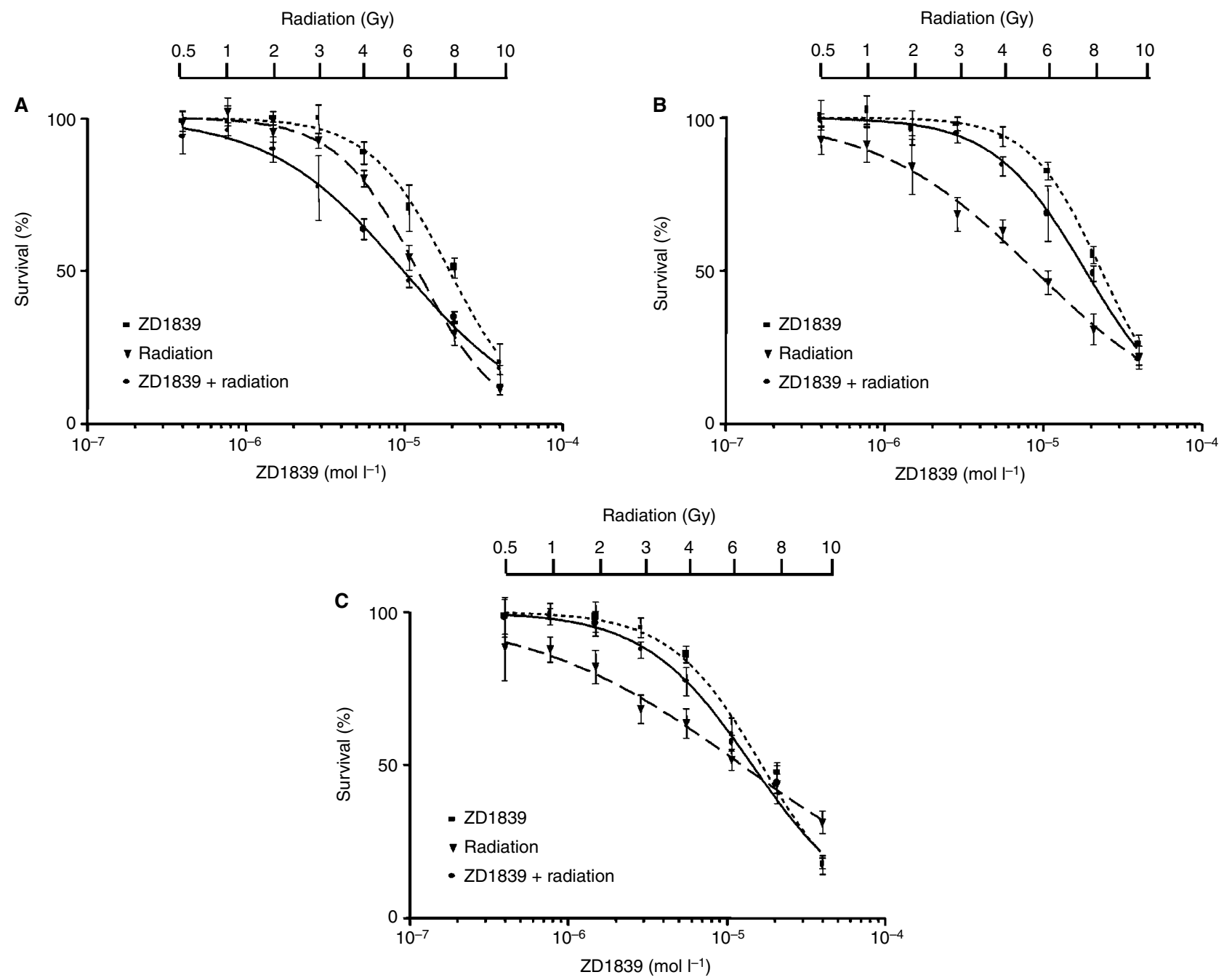

Figure 3 Dose-effect curves for the different ZD 1839/radiation exposure combinations for CAL33 cells: (A) sequence I, (B) sequence II, (C) sequence III. For each combination sequence of ZDI839 and radiation, the dose-effect curve of the combination was compared with the dose-effect curves of ZDI 839 alone and radiation alone. Radiation dose ranged from 0.5 to $10 \mathrm{~Gy}$.

Table $2 \mathrm{Cl}$ values ${ }^{\mathrm{a}}$ according to the different sequences of ZD/839/radiation

\begin{tabular}{|c|c|c|c|c|c|c|}
\hline \multirow[b]{2}{*}{ Cell line } & \multicolumn{3}{|c|}{$50 \% \mathrm{Cl}$} & \multicolumn{3}{|c|}{$75 \% \mathrm{Cl}$} \\
\hline & Sequence I & Sequence II & Sequence III & Sequence I & Sequence II & Sequence III \\
\hline CAL27 & $0.4(0.1)$ & $1.5(0.1)$ & $3.1(0.1)$ & $0.8(0.4)$ & $1.5(0.1)$ & $3.1(1.0)$ \\
\hline CAL33 & $0.5(0.1)$ & $1.1(0.1)$ & $1.9(0.2)$ & $0.8(0.0)$ & $1.6(0.8)$ & $2.8(0.3)$ \\
\hline CAL60 & $0.7(0.0)$ & $0.7(0.1)$ & $1.4(0.1)$ & $0.5(0.1)$ & $0.9(0.2)$ & $1.7(0.2)$ \\
\hline CALI66 & $0.9(0.1)$ & $2.1(0.3)$ & $1.8(0.1)$ & $2.2(0.4)$ & $1.5(0.1)$ & $1.8(0.3)$ \\
\hline Hep-2 & $0.9(0.7)$ & $2.5(0.0)$ & $2.9(1.2)$ & $1.3(0.3)$ & $2.2(1.0)$ & $1.1(0.2)$ \\
\hline Detroit562 & $1.2(0.1)$ & $16.2(3.2)$ & $2.2(0.4)$ & $1.1(0.2)$ & $15.2(0.2)$ & $2.0(0.3)$ \\
\hline
\end{tabular}

${ }^{a} 50$ and $75 \%$ mean (standard deviation) $\mathrm{Cl}$ values (at least three separate experiments) computed at 50 and $75 \%$ of growth inhibitory effects; sequence I, ZD I839 applied before radiation; sequence II ZD I839 applied during radiation; sequence III, ZD I839 applied after radiation. The Friedman non-parametric rank test was used to analyse the impact of the sequence of treatment on the whole cell line panel, $P=0.002$

the tumoural content of its specific ligands may play an important role in radiosensitivity. Cell doubling time and EGFR content were not found to be correlated in the present study. Thus the impact of EGFR on radiosensitivity is not explicable by EGFR-dependent modifications of cell kinetic characteristics, which could enhance the action of irradiation. The classical view of the cellular effects of ionising radiation consists of an initial event involving the induction of DNA damage, in addition to the activation of several intracellular signalling cascades that have commonly been regarded as mitogenic, including the Raf-MEK-Erk kinase cascade (Todd et al, 1999). DNA damage is modulated by metabolic DNA repair processes. Interestingly, Bandyopadhyay et al (1998) have shown that EGFR-mediated signalling may control the activity of DNA$\mathrm{PK}$, an enzyme directly involved in DNA damage repair; more 
A

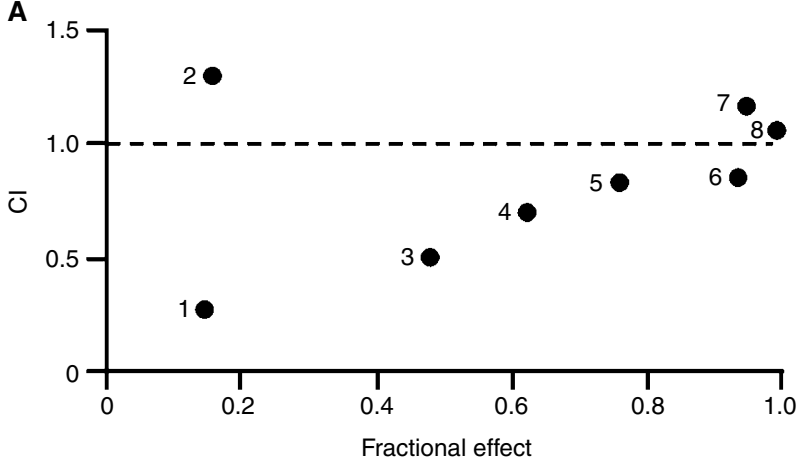

B

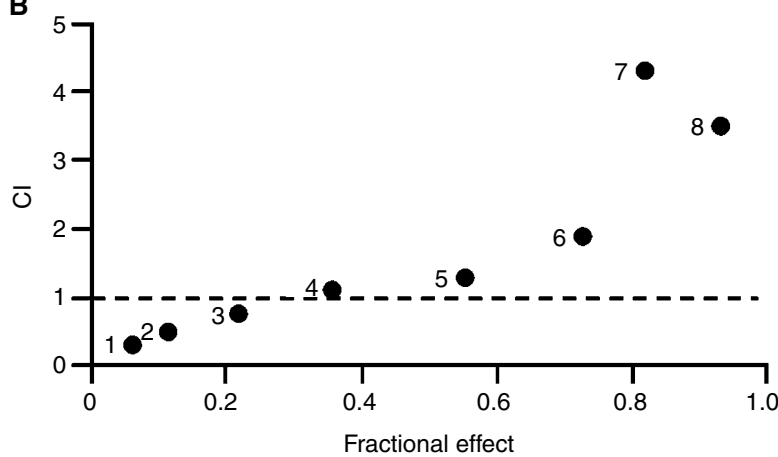

C

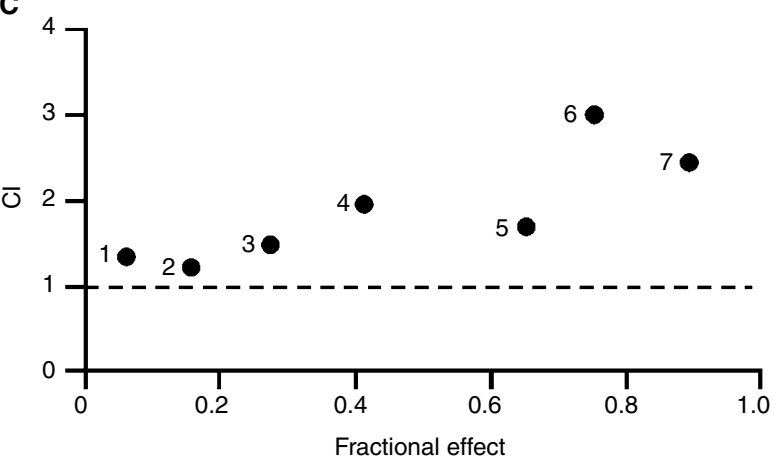

Figure 4 Typical examples of Cl/fractional effects curves for CAL33 cells: (a) sequence I, (b) sequence II, (c) sequence III.

Table 3 Values of potentiation factors ${ }^{\mathrm{a}}$ of ionising radiation by ZDI839

\begin{tabular}{lccc}
\hline Cell line & $\begin{array}{c}\text { Potentiation } \\
\text { factor I }\end{array}$ & $\begin{array}{c}\text { Potentiation } \\
\text { factor II }\end{array}$ & $\begin{array}{c}\text { Potentiation } \\
\text { factor III }\end{array}$ \\
\hline CAL27 & $2.7(0.2)$ & $2.2(2.0)$ & $0.5(0.1)$ \\
CAL33 & $2.3(1.5)$ & $1.5(1.4)$ & $0.1(0.1)$ \\
CAL60 & $3.7(0.1)$ & $0.5(0.1)$ & $0.6(0.1)$ \\
CAL166 & $3.2(0.4)$ & $0.5(0.2)$ & $0.8(0.1)$ \\
Hep-2 & $7.5(2.1)$ & $2.0(0.8)$ & $1.0(0.2)$ \\
Detroit562 & $3.1(0.0)$ & $2.5(0.0)$ & $0.8(0.1)$ \\
\hline
\end{tabular}

aMean (standard deviation) potentiation factor values (at least three separate experiments); statistical analysis (Friedman non-parametric rank test) was used to compare the different sequences combining ZDI839 and radiation on the basis of the potentiation factors on the whole cell line panel, $P=0.03$.

precisely, from their work, high EGFR expression could maintain a high level of signalling, which would be associated with high basal levels of DNA repair capacity. However, this does not appear to explain the observations reported here. An approach used by Lewis et al (2000), examining the whole pattern of MAP kinase pathway signalling targets, could help to elucidate the molecular origins of the present observation of a radiosensitivity linked to high tumoural EGFR levels.

A strong positive interaction between irradiation and ZD1839, when the ZD1839 was applied before the radiation, was demonstrated in the present study (Tables 2 and 3 ). This could be explained by an intrinsic activity of ZD1839 as radiosensitiser, as has previously been shown for cetuximab, another EGFR-targeting drug (Ezekiel et al, 1999; Huang et al, 1999; Mendelsohn et al, 1999; Baselga et al, 2000; Huang and Harari, 2000; Milas et al, 2000), and also for trastuzumab (Herceptin ${ }^{\mathrm{TM}}$ ), a HER-2-targeting drug (Pegram et al, 1998; Pietras et al, 1999; Pegram and Slamon, 2000). Trastuzumab increased the radiosensitivity of HER-2-overexpressing MCF7 breast cancer cells as measured by in vitro colony-forming assays, and the combination of trastuzumab and radiation showed synergistic tumour reduction in nude mice (Pietras et al, 1999). According to Pietras et al (1999) the mechanism of radiosensitization appears to involve both cell cycle regulation and DNA repair. Interestingly, the application of ZD1839 in our study was found to increase the percentage of cells in the G1 phase (results not shown), which are particularly sensitive to radiation (Teyssier et al, 1999). Thus, there are several potential mechanisms of radiosensitisation by inhibitors of the EGFR family; they may include favourable cell cycle reorganisation and/or abrogation or attenuation of signals required for survival during cell cycle arrest. Marked antagonistic effects were observed when exposing cells to ZD1839 after irradiation (sequence III). This observation may be related to the fact that irradiation is able to upregulate EGFR phosphorylation in a similar manner to EGF (Wan et al, 2001) and thus create the circonstances of opposite effects to ZD1839.

Two cell lines of the initial panel of six were considered for analysis of the association between ZD1839 and cytotoxic drugs. We have recently demonstrated an inverse correlation between p53 content (representative of p53 mutations) and EGFR levels in a group of HNC patients (Etienne et al, 1999). Thus, the two cell lines were selected because they are representative of human HNC characteristics on the basis of their p53 status and EGFR status: CAL33 is p53 mutant and has high EGFR expression, and Hep-2 is p53 wild type and has low EGFR expression. We observed synergistic effects when ZD1839 was applied before cisplatin and/or 5 -FU in both cell lines (Table 4). The impact of ZD1839 on the effects of the combined drugs was sequence dependent. The highest synergistic effects were obtained when ZD1839 was applied before and during exposure to cytotoxic drugs (Table 4). Previous in vivo and in vitro studies have shown that the anti-EGFR receptor monoclonal antibody C225 can potentiate the effects of a number of chemotherapeutic agents, including doxorubicin, paclitaxel and cisplatin (Ezekiel et al, 1999; Mendelsohn et al, 1999; Huang et 
Table $4 \mathrm{Cl}$ results in Hep-2 and CAL33 cell lines corresponding to concentration of drugs leading to 50\% cell survival

\begin{tabular}{|c|c|c|c|c|}
\hline \multirow[b]{2}{*}{ Treatment } & \multicolumn{2}{|c|}{ Hep-2 } & \multicolumn{2}{|c|}{ CAL33 } \\
\hline & $50 \% \mathrm{Cl}$, mean (s.d.) & Combination effect & $50 \% \mathrm{Cl}$, mean (s.d.) & Combination effect \\
\hline \multicolumn{5}{|l|}{ Prior exposure to ZDI839 } \\
\hline ZDI839+cisplatin & $0.9(0.2)$ & Additive & $0.8(0.1)$ & Synergistic \\
\hline ZDI839+5-FU & $0.6(0.1)$ & Synergistic & $0.7(0.3)$ & Synergistic \\
\hline ZDI839+cisplatin+5-FU & $0.8(0.1)$ & Synergistic & $0.7(0.1)$ & Synergistic \\
\hline \multicolumn{5}{|c|}{ Concomitant exposure to ZDI839 } \\
\hline ZDI839+cisplatin & I.I (0.5) & Additive & $1.2(0.6)$ & Additive \\
\hline ZDI839+5-FU & $0.8(0.3)$ & Synergistic & $1.5(0.3)$ & Antagonistic \\
\hline ZDI839+cisplatin+5-FU & $1.3(0.4)$ & Antagonistic & I.I (0.5) & Additive \\
\hline \multicolumn{5}{|c|}{ Prior and concomitant exposure to ZDI839 } \\
\hline ZDI839+cisplatin+5-FU & $0.6(0.2)$ & Synergistic & $0.4(0.2)$ & Synergistic \\
\hline \multicolumn{5}{|c|}{ Exposure to ZDI839 after cisplatin and/or 5-FU } \\
\hline ZD1839+cisplatin & $1.4(0.3)$ & Antagonistic & I.I (0.2) & Additive \\
\hline ZDI839+5-FU & $1.0(0.2)$ & Additive & $1.3(0.8)$ & Antagonistic \\
\hline ZDI839+cisplatin+5-FU & $1.5(0.4)$ & Antagonistic & $1.4(0.8)$ & Antagonistic \\
\hline
\end{tabular}

At least three separate experiments; ZDI839 applied for 48 h; cisplatin for 2 h; 5-FU for 48 h.

A

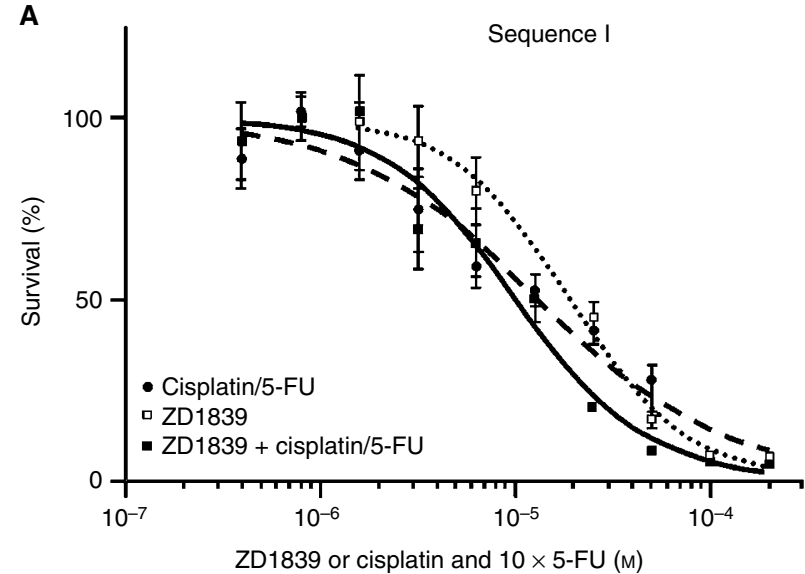

C

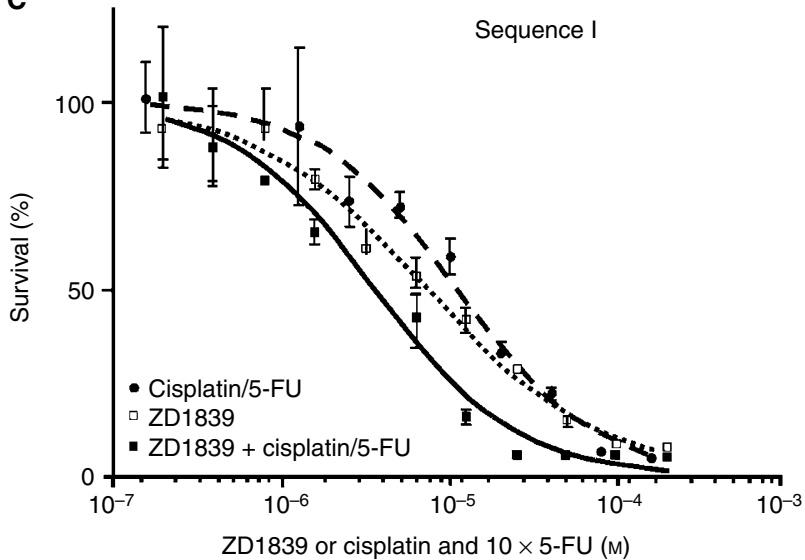

B

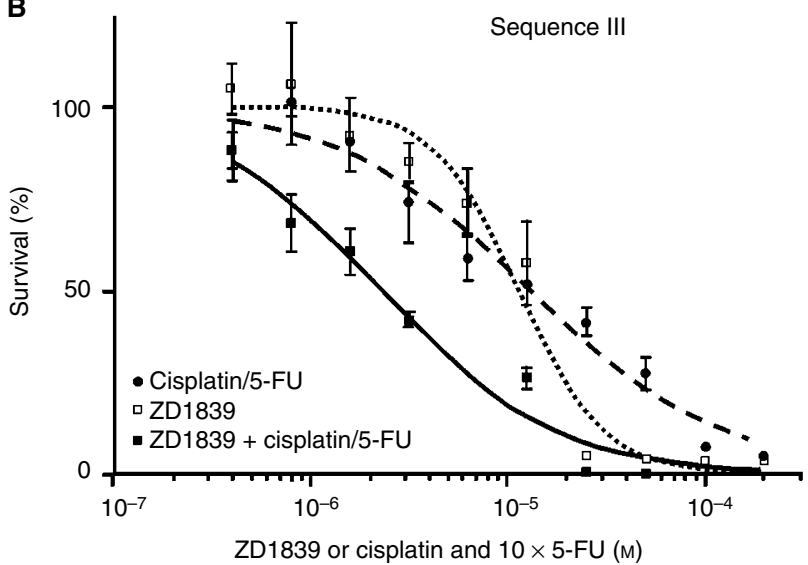

D

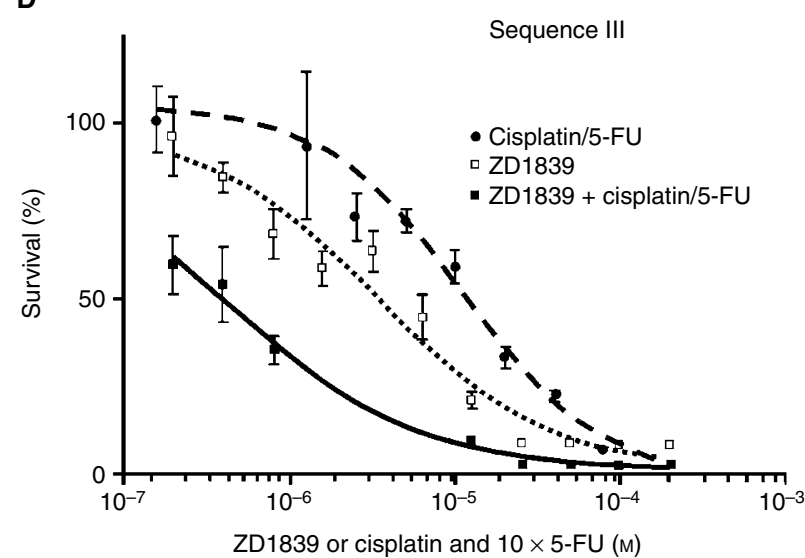

Figure 5 Typical dose-effect curves comparing sequences I and III for (A, B) Hep-2 and (C. D) CAL33. Sequence I consisted of ZDI 839, followed by cisplatin/5-FU for 48 h; sequence III was ZDI839 applied first and also during the cisplatin/5-FU exposure, followed by medium for 48 h.

al, 1999; Baselga et al, 2000; Huang and Harari, 2000; Milas et al, 2000). The mechanisms by which receptor blockade by C225 augments the cytotoxic effect of anti-neoplastic agents was attributed by these authors to cell cycle effects and an enhanced capacity for apoptosis by C225. The antiproliferative activity of ZD1839 combined with a number of cytotoxic drugs (cisplatin, carboplatin, oxaliplatin, paclitaxel, docetaxel, doxorubibin, etoposide, topotecan and raltitrexed) has been recently assessed in a variety of human cancer cell lines (Ciardiello et al, 2000; Sirotnak et al, 2000). The co-administration of ZD1839 was found to enhance the growth- 
inhibitory effects of all cytotoxic drugs tested. The present data confirm this interesting property of ZD1839 as a strong radioand chemosensitizer. In addition, the present study brings particular focus to the importance of the combination sequence: it is shown that synergy is not a rule and that some antagonistic effects may result from inappropriate sequences, e.g. where ZD1839 is applied after the cytotoxic drugs (Table 4). In conclusion, the present investigations into the combinations of ZD1839 and radiation, and ZD1839 and cisplatin/5-FU, led to similar findings of sequence-dependent synergy. Although an unavoidable gap does exist between the bench and the bed side, these data may be useful

\section{REFERENCES}

Akimoto T, Hunter NR, Buchmiller L, Mason K, Ang KK, Milas L (1999) Inverse relationship between epidermal growth factor receptor expression and radiocurability of murine carcinomas. Clin Cancer Res 5: 2884-2890

Bandyopadhyay D, Mandal M, Adam L, Mendelsohn J, Kumar R (1998) Physical interaction between epidermal growth factor receptor and DNA-dependent protein kinase in mammalian cells. J Biol Chem 273: $1568-1573$

Baselga J, Pfister D, Cooper MR, Cohen R, Burtness B, Bos M, D’Andrea G, Seidman A, Norton L, Gunnett K, Falcey J, Anderson V, Waksal H, Mendelsohn J (2000) Phase I studies of anti-epidermal growth factor receptor chimeric antibody $\mathrm{C} 225$ alone and in combination with cisplatin. J Clin Oncol 18: $904-914$

Bensadoun RJ, Etienne MC, Dassonville O, Chauvel P, Pivot X, Marcy PY, Prevost B, Coche-Dequeant B, Bourdin S, Vallicioni J, Poissonnet G, Courdi A, Teissier E, Lagrange JL, Thyss A, Santini J, Demard F, Schneider M, Milano G (1998) Concomitant B.I.D. radiotherapy and chemotherapy with cisplatin and 5-fluorouracil in unresectable squamous-cell carcinoma of the pharynx: clinical and pharmacological data of a French multicenter phase II study. Int J Radiat Oncol Biol Phys 42: 237-245

Bonner JA, Maihle NJ, Folven BR, Christianson TJH, Spain K (1994) The interaction of epidermal growth factor and radiation in human head and neck squamous cell carcinoma cell lines with vastly different radiosensitivity. Int J Radiat Oncol Biol Phys 29: 243 - 247

Bonner JA, Vroman BT, Christianson THJ, Karnitz LM (1998) Ionizing radiation-induced MEK and ERK activation does not enhance survival of irradiated human squamous carcinoma cells. Int J Radiat Oncol Biol Phys 42: $921-925$

Bonner JA, Raish KP, Trummell HQ, Robert F, Meredith RF, Spencer SA, Bushbaum DJ, Saleh MN, Stackhouse MA, LoBuglia AF, Peters GE, Caroll WR, Waksal HW (2000) Enhanced apoptosis with combination C225/ radiation treatment serves as the impetus for clinical investigation in head and neck cancers. J Clin Oncol 18: $47-53$

Brizel DM, Albers ME, Fisher SR, Scher RL, Richtsmeier WJ, Hars V, George SL, Huang AT, Prosnitz LR (1998) Hyperfractionated irradiation with or without concurrent chemotherapy for locally advanced head and neck cancer. N Engl J Med 338: $1798-1804$

Cabelguenne A, Blons H, de Waziers I, Carnot F, Houllier AM, Soussi T, Brasnu D, Beaune P, Laccourreye O, Laurent-Puig P (2000) P53 alterations predict tumor response to neoadjuvant chemotherapy in head and neck squamous cell carcinoma: a prospective series. J Clin Oncol 18: 1465-1473

Calais G, Alfonsi M, Bardet E, Sire C, Germain T, Bergerot P, Rhein B, Tortochaux J, Oudinot P, Bertrand P (1999) Randomized trial of radiation therapy versus concomitant chemotherapy and radiation therapy for advanced-stage oropharynx carcinoma. J Nat Cancer Inst 91: 2081-2086

Carmichael J, De Graff WG, Gazdar AF, Minna JD, Mitchell JB (1987) Evaluation of a tetrazolium-based semiautomated colorimetric assay: assessment of chemosensitivity testing. Cancer Res 47: 936-940

Chou T, Talalay P (1984) Quantitative analysis of dose-effects relationships: the combined effects of multiple drugs or enzyme inhibitors. Adv Enzyme Regul 22: $27-55$

Ciardiello F, Caputo R, Bianco R, Damiano V, Pomatico G, De Placido S, Bianco AR, Tortora G (2000) Antitumor effect and potentiation of cytotoxic drugs activity in human cancer cells by ZD-1839 (Iressa $^{\mathrm{TM}}$ ), an epidermal growth factor receptor-selective tyrosine kinase inhibitor. Clin Cancer Res 6: $2053-2063$ for the design of future clinical trials combining ZD1839 and cytotoxic agents.

\section{ACKNOWLEDGEMENTS}

Ligue Régionale de lutte contre le Cancer and AstraZeneca group for financial support. Results presented in part during the 2001 meeting of the American Association for Cancer Research (AACR). 'Iressa' is a trade mark of the AstraZeneca group of companies.

Dassonville O, Formento JL, Francoual M, Ramaioli A, Santini J, Schneider M, Demard F, Milano G (1993) Expression of epidermal growth factor receptor and survival in upper aerodigestive tract cancer. J Clin Oncol 11: $1873-1878$

Dent P, Reardon DB, Park JS, Bowers G, Logsdon C, Valerie K, SchmidtUlrich R (1999) Radiation-induced release of transforming growth factor $\alpha$ activates the epidermal growth factor receptor and mitogen-activated protein kinase pathway in carcinoma cells, leading to increased proliferation and protection from radiation-induced cell death. Mol Biol Cell 10: $2493-2506$

Etienne MC, Pivot X, Formento JL, Bensadoun RJ, Formento P, Dassonville O, Francoual M, Poissonnet G, Fontana X, Schneider M, Demard F, Milano G (1999) A multifactorial approach including tumoural epidermal growth factor receptor, p53, thymidylate synthase and dihydropyrimidine dehydrogenase to predict treatment outcome in head and neck cancer patients receiving 5-fluorouracil. Br J Cancer 79: 1864-1869

Ezekiel MP, Bonner JA, Robert F, Meredith RF, Spencer SA, LoBuglio AF, Waksal HW (1999) Phase I trial of chimerized anti-epidermal growth factor receptor (anti-EGFR) antibody in combination with either oncedaily or twice-daily irradiation for locally advanced head and neck malignancies. Proc Am Soc Clin Oncol 18: 388a (abstract 1501)

Fu KK, Pajak TF, Trotti A, Jones CU, Spencer SA, Phillips TL, Garden AS Ridge JA, Cooper JS, Ang KK (2000) A radiation therapy oncology group (RTOG) phase III randomized study to compare hyperfractionation and two variants of accelerated fractionation to standard fractionation radiotherapy for head and neck squamous cell carcinomas: first report of RTOG 9003. Int J Radiat Oncol 48: 7-16

Grandis JR, Melhem MF, Barnes EL (1996) Quantitative immunohistochemical analysis growth factor-alpha and epidermal growth factor receptor in patients with squamous cell carcinoma of the head and neck. Cancer 78: $1284-1292$

Grandis JR, Melhem MF, Gooding WE, Day R, Holst VA, Wagener MM, Drening SD, Tweardy DJ (1998) Levels of TGF-alpha and EGFR protein in head and neck squamous cell carcinoma and patient survival. J Natl Cancer Inst 90: 824-832

Gulberg P, Nedergaard T, Nielsen HJ, Olsen AC, Ahenkiel V, Zeuthen J (1997) Single-step DGGE-based mutation scanning of the p53 gene: application to genetic diagnosis of colorectal cancer. Hum Mutat 9: 348-355

Hamelin R, Jego N, Laurent-Puig P, Vidaud M, Thomas G (1993) Efficient screening of p53 mutations by denaturing gradient gel electrophoresis in colorectal tumors. Oncogene 8: 2213 - 2220

Huang SM, Bock JM, Harari PM (1999) Epidermal growth factor receptor blockade with C225 modulates proliferation, apoptosis, and radiosensitivity in squamous cell carcinomas of the head and neck. Cancer Res 59: $1935-1940$

Huang SM, Harari PM (2000) Modulation of radiation response after epidermal growth factor receptor blockade in squamous cell carcinomas: inhibition of damage repair, cell cycle kinetics, and tumor angiogenesis. Clin Cancer Res 6: $2166-2174$

Kwok TT, Sutherland RM (1989) Enhancement of sensitivity of human squamous carcinoma cells to radiation by epidermal growth factor. J Nat Cancer Inst 81: $1020-1024$

Kwok TT, Sutherland RM (1991) Differences in EGF-related radiosensitization of human squamous carcinoma cells with high and low numbers of EGF receptors. Br J Cancer 64: $251-254$ 
Lewis TS, Hunt JB, Aveline LD, Jonscher KR, Louie DF, Yeh JM, Naheini TS, Resing KA, Ahn NG (2000) Identification of novel MAP kinase pathway signaling targets by functional proteomics and mass spectrometry. Mol Cell 6: $1343-1354$

Maurizi M, Almadori G, Ferrandina G, Distefano M, Romanini ME, Cadoni G, Benedetti-Pacini P, Paludetti G, Scambia G, Mancuso S (1996) Prognostic significance of epidermal growth factor receptor in laryngeal squamous cell carcinoma. Br J Cancer 74: $1253-1257$

Mendelsohn J, Shin DM, Donato N, Khuri F, Radinsky R, Glisson BS, Shin HJ, Metz E, Pfister D, Perez-Soler R, Lawhorn K, Matsumoto T, Gunnet K, Falcey J, Waksal H, Hong WK (1999) Phase I study of chimerized anti-epidermal growth factor receptor (EGFR) monoclonal antibody, $\mathrm{C} 225$, in combination with cisplatin (CDDP) in patients (PTS) with recurrent head and neck and squamous cell carcinoma (SCC). Proc Am Soc Clin Oncol 18: 389a (abstract 1502)

Milas L, Mason K, Hunter N, Petersen S, Yamakawa M, Ang K, Mendelsohn J, Fan Z (2000) In vivo enhancement of tumor radioresponse by C225 antiepidermal growth factor receptor antibody. Clin Cancer Res 6: 701-708

Miyaguchi M, Takeuchi T, Morimoto K, Kubo T (1998) Correlation of epidermal growth factor receptor and radiosensitivity in human maxillery carcinoma cell lines. Acta Otolaryngol 118: $428-431$

Olivier S, Formento P, Fischel JL, Etienne MC, Milano G (1990) Epidermal growth factor receptor expression and suramin cytotoxicity in vitro. Eur J Cancer 26: $867-871$

Pegram MD, Lipton A, Hayes DF, Weber BL, Baselga JM, Tripathy D, Baly D, Baughman SA, Twaddell T, Glaspy JA, Slamon DJ (1998) Phase II study receptor-enhanced chemosensitivity using recombinant humanized antip185HER2/ neu monoclonal antibody plus cisplatin in patients with HER2/ neu-overexpressing metastatic breast cancer refractory to chemotherapy treatment. J Clin Oncol 16: 2659-2671

Pegram M, Slamon D (2000) Biological rationale for HER2/neu (c-erbB2) as a target for monoclonal antibody therapy. Semin Oncol 27: 13-19

Pietras RJ, Poen JC, Gallardo D, Wongvipat PN, Lee HJ, Slamon DJ (1999) Monoclonal antibody to HER-2/neu receptor modulates repair of radiation-induced DNA damage and enhances radiosensitivity of human breast cancer cells overexpressing this oncogene. Cancer Res 59: $1347-$ 1355

Pignon JP, Bourhis J, Domenge C, Designé L (2000) Chemotherapy added to locoregional treatment for head and neck squamous-cell carcinoma: three meta-analyses of updated individual data. Lancet 355: 949-955

Salomon DS, Bradt R, Ciardello F, Normanno N (1995) Epidermal growth factor-related peptides and their receptors in human malignancies. Crit Rev Oncol Hematol 19: 183-232
Santini J, Formento JL, Francoual M, Milano G, Schneider M, Dassonville O, Demard F (1991) Characterization, quantification and potential clinical value of the epidermal growth factor receptor in head and neck squamous cell carcinomas. Head Neck 13: $132-139$

Sauter ER, Coia LR, Eisenberg BL, Ridge JA (1994) Radiation treatment decreases transforming growth factor alpha expression in squamous carcinoma of the tongue. Cancer Lett 78: 159-162

Schlessinger J (2000) Cell signaling by receptor tyrosine kinases. Cell 103: $211-225$

Sirotnak FM, Zakowski MF, Miller VA, Scher HI, Kris MG (2000) Efficacy of cytotoxic agents against human tumor xenografts is markedly enhanced by coadministration of ZD1839 (Iressa), an inhibitor of EGFR tyrosine kinase. Clin Cancer Res 6: 4885-4892

Taylor SG, Murthy AK, Griem KL, Recine DC, Kiel K, Blendowski C, Hurst PB, Showel JT, Hutchinson JC, Campanella RS, Chen S, Caldarelli DD (1997) Concomitant cisplatin/5-FU infusion and radiotherapy in advanced head and neck cancer: 8-year analysis of results. Head Neck 19: 684-691

Teyssier F, Bay JO, Dionet C, Verelle P (1999) Cell cycle regulation after exposure to ionizing radiation. Bull Cancer 86: $345-357$

Todd DG, Mikkelsen RB, Rorrer WK, Valerie K, Schmidt-Ulrich RK (1999) Ionizing radiation stimulates existing signal transduction pathways involving the activation of epidermal growth factor receptor and erbB-3, and changes of intracellular calcium in A431 human squamous carcinoma cells. J Recept Signal Transduct Res 19: 885-908

Vokes EE, Weichselbaum RR, Lipman SM, Hong WK (1993) Head and neck cancer. N Engl J Med 328: 184-194

Vokes EE, Kies MS, Haraf DJ, Stenson K, List M, Humerickhouse R, Dolan ME, Pelzer H, Sulzen L, Witt ME, Hsieh YC, Mittal BB, Weichselbaum RR (2000) Concomitant chemoradiotherapy as primary therapy for locoregionally advanced head and neck cancer. J Clin Oncol 18: 1652-1661

Wan YS, Wang ZQ, Voorhees J, Fisher G (2001) EGF receptor crosstalks with cytokine receptors leading to the activation of c-Jun kinase in response to UV irradiation in human keratinocytes. Cell Signal 13: 139-144

Wen QH, Miwa T, Yoshikazi T, Nagayama M, Nishijima H (1996) Prognostic value of EGFR and TGF-alpha in early laryngeal cancer treated with radiotherapy. Laryngoscope 106: $884-888$

Wheeler RH, Spencer S, Buchsbaum D, Robert F (1999) Monoclonal antibodies as potentiators of radiotherapy and chemotherapy in the management of head and neck cancer. Curr Opin Oncol 11: 187-190

Wollman R, Yahalom J, Maxy R, Pinto J, Fuks Z (1994) Effect of epidermal growth factor on the growth and radiation sensitivity of human breast cancer cells in vitro. Int J Radiat Oncol Biol Phys 30: 91-98 